\title{
透析息者の婜急大動脈解離手術に対して 体外循環復温中，人工透析を施行した I 症例
}

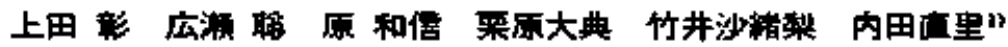

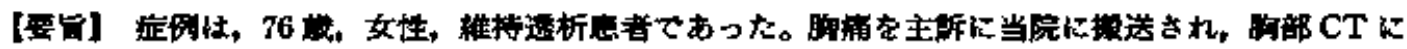

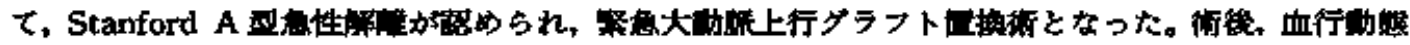

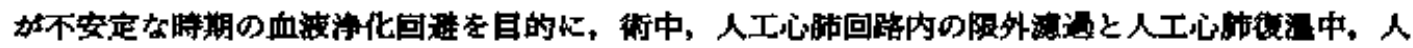

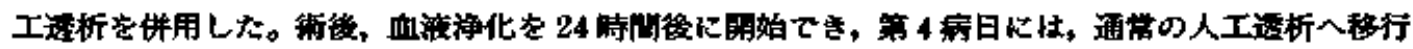

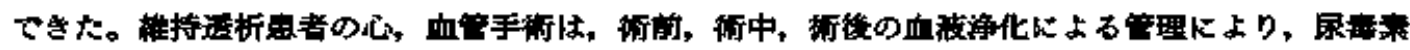

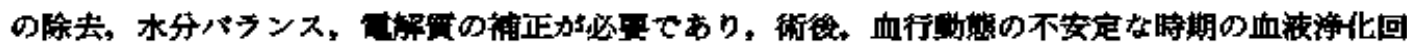

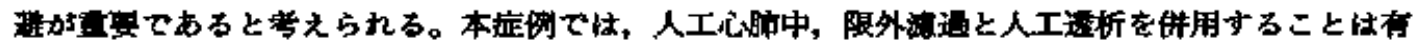

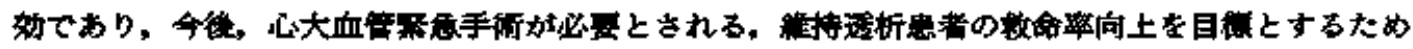

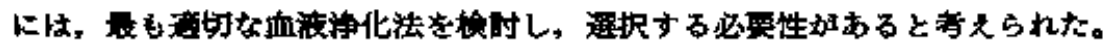

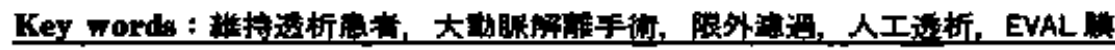

\section{I.はしめに}

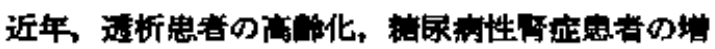

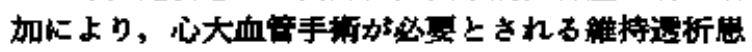
者が简加している。

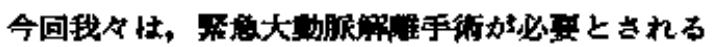

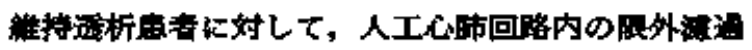
(以下, ECUM) と，人工心肺推温中に人工这析(以

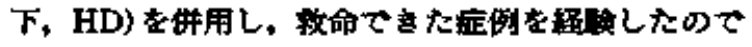
埌告する。

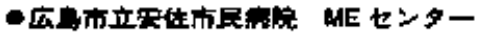
1)
同
心证些科

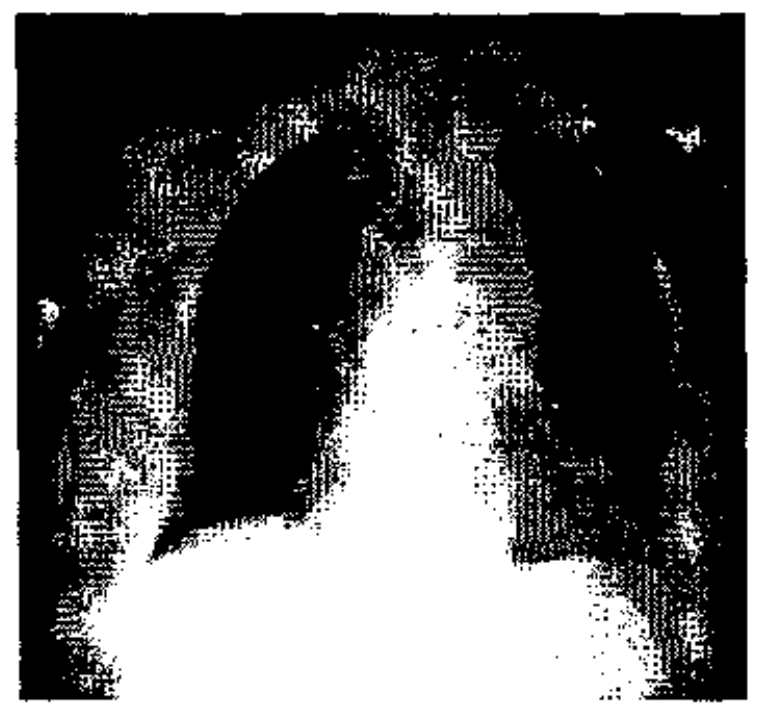

图 I 朐部 X罗高

\section{II. 鿊 例}

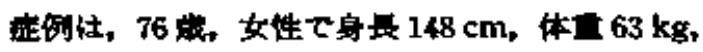

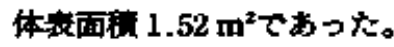

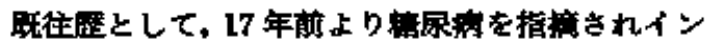

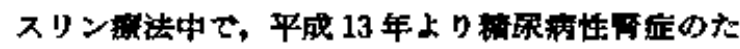
わ, HD率入となった。

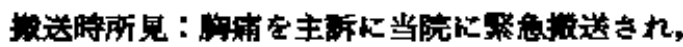

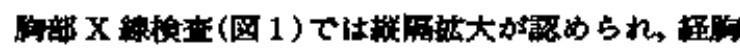

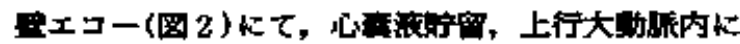

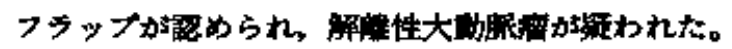

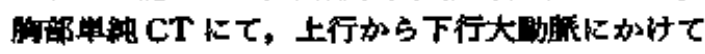

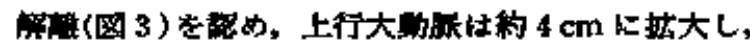

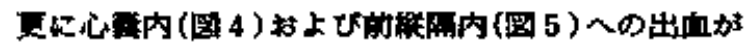

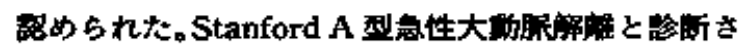

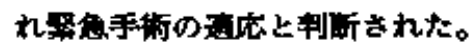

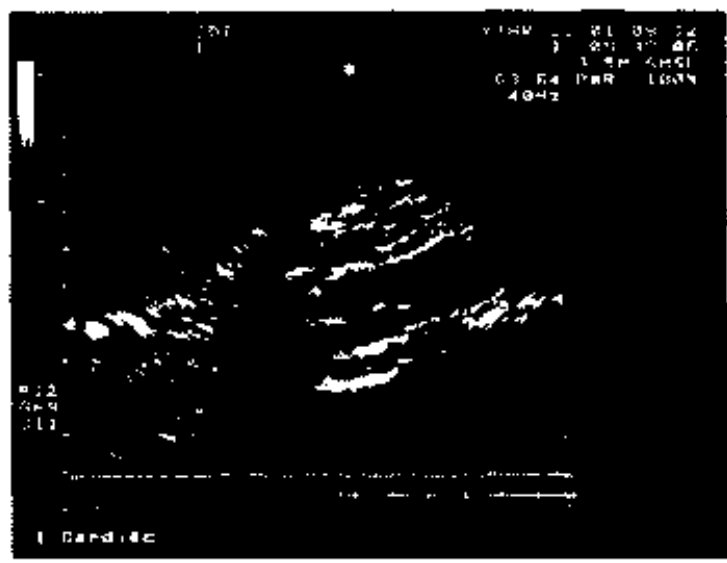

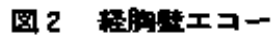


来院時の血液検查所見は, BUN $65 \mathrm{mg} / \mathrm{dL}$, Cr $8.0 \mathrm{mg} / \mathrm{dL}$, 血清 K $5.5 \mathrm{mEq} / \mathrm{dL}$, Hct $36.2 \%$ で あった。

なお，来院時が予定透析日であった。大動脈解離 手術前にHD を行うと破裂死する危険性が非常に 高く, また術直後より HD を行うと出血や循環動態 の変動が激しく危険性が高いことから，特に人工心 肺中にHDを併用することにした。人工心肺中 ECUM と併せて, 人工心肺復温中から HD を併用 した。HDは,ブラットアクセスに FDL (flexible double lumen) カテーテルを右大俍静脈に留置し使 用した。術中配置を図 6 に示す。

\section{I. 術中経恧 (表 1)}

ECUM は, 人工心肺開始から終了まで, 水分バラ ンスと血清 $\mathrm{K}$ などを, 連続モニターで監視しながら 積極的に補液と除水を施行した。

HD は, 血液流量 $180 \mathrm{~mL} / \mathrm{mil}$, 透析流量 $650 \mathrm{~mL} /$

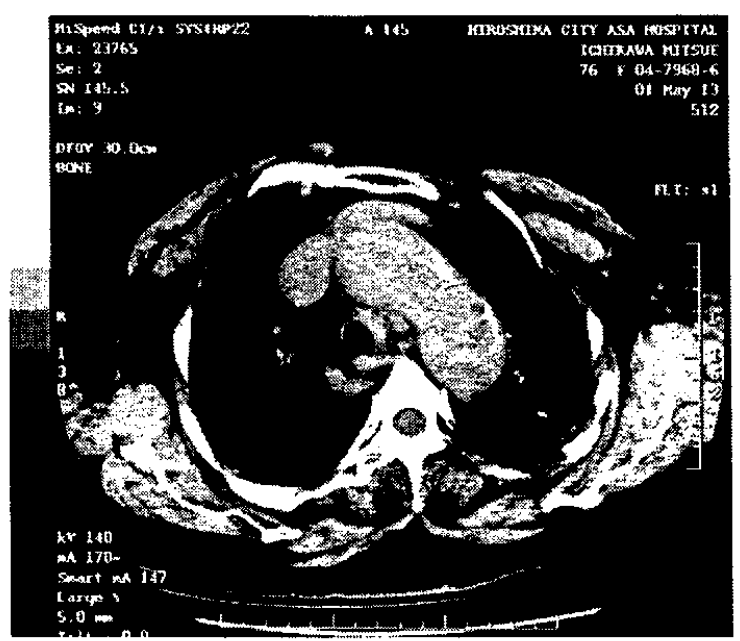

図 3 単純 CT 造影大動脈

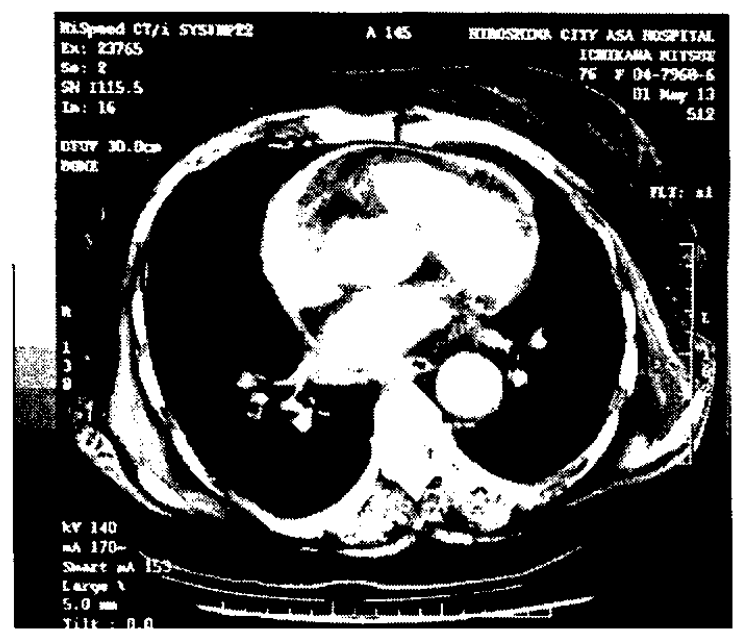

图 4 単純 CT 造影心高内
表 | 術中経過

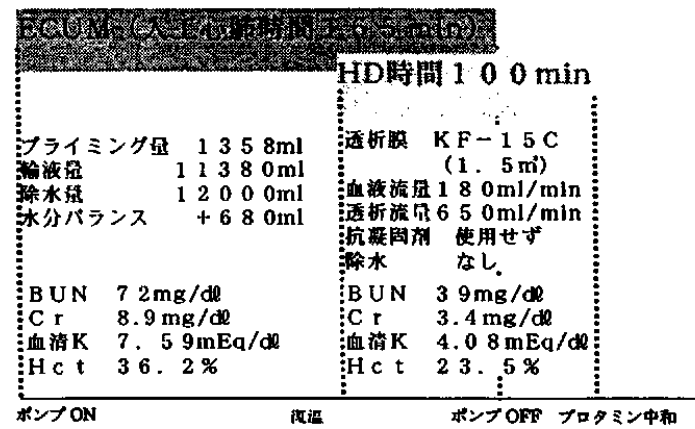

$\min$, 除水 $0 \mathrm{~mL}$ に設定し, 大動脈遮断解除後, 人工 心肺復温開始からプロタミン中和まで施行した。ま た，HDの透析膜には，クラレ社製 $\mathrm{KF}-15 \mathrm{C}$ (以下, EVAL 膜), 膜面積 $1.5 \mathrm{~m}^{2}$ を使用し, 人工心肺中であ ったことから回路局所の抗凝固剂は使用しなかった。

人工心肺(ECUM) 時間は 165 分, HD は時間 100 分であった。

2. 術後経過 (表 2)

術後は, ICU で全身管理を行った。

第 1 病日に, CVP が最高値 $21 \mathrm{mmHg}$ を示し, 呼

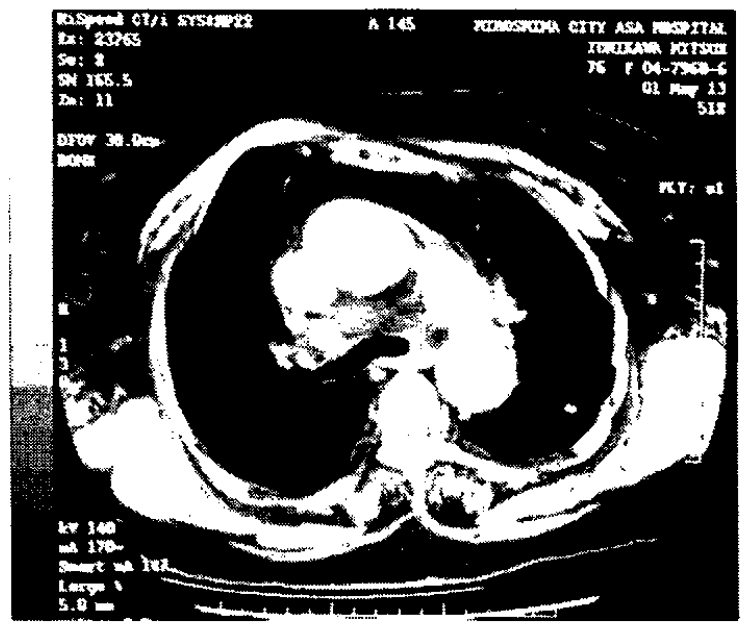

図 5 単純 CT 造影前縦䧣

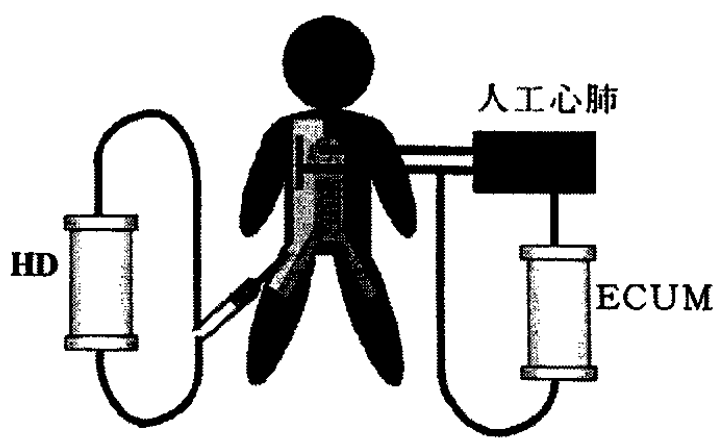

図 6 配置図 
表 2 術後経過

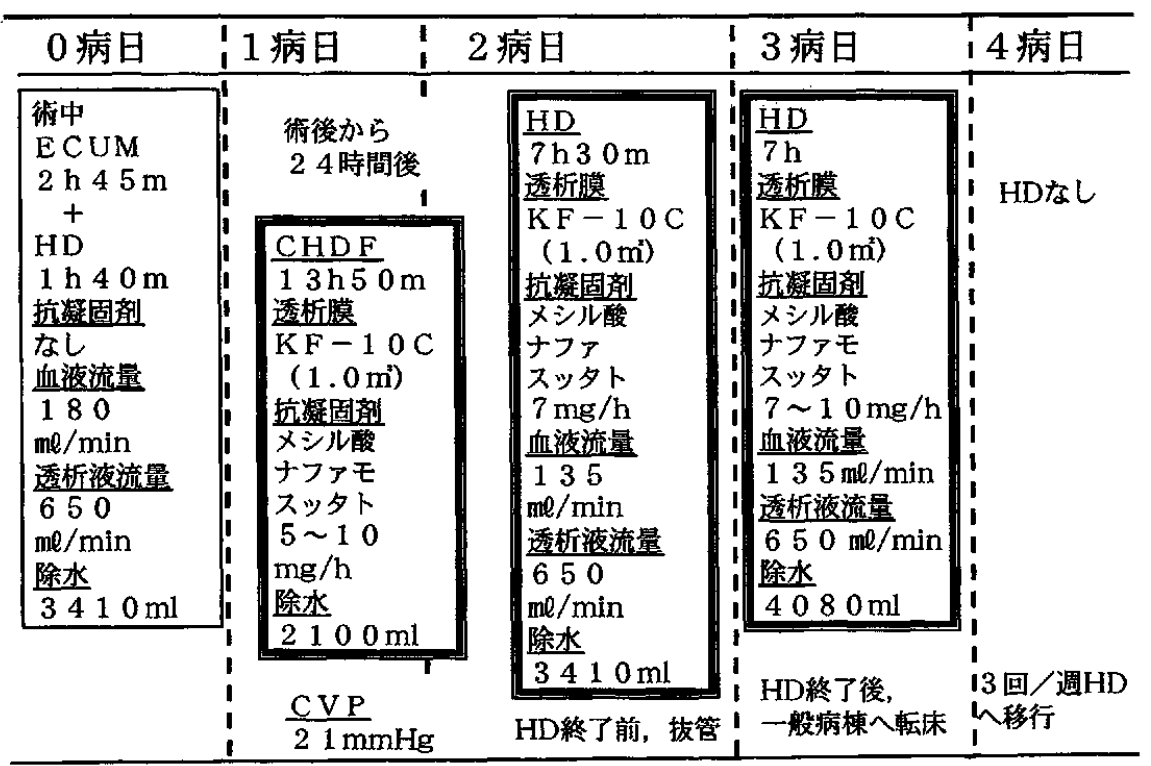

吸状態の悪化が認められ,術後 24 時間後より持続緩 徐式血液滤過法 (以下, CHDF) 13 時間 50 分行 い, その間計 $2,100 \mathrm{~mL}$ 除水した。

第 2 病日は, CHDF 終了から 6 時間経過してお り, 血行動態も安定していたため, HD を 7 時間 30 分, 設定は血液流量 $135 \mathrm{~mL} / \mathrm{min}$, 透析液流量 650 $\mathrm{mL} / \mathrm{min}$, 除水 $3,410 \mathrm{~mL}$ を施行した。HD 終了前に は，酸素化が良好であったため抜管できた。

第 3 病日は, HD を 7 時間, 設定は同条件で, 除水 4,080 mL を施行した後, 一般病棟へ転床となった。

計 3 回の血液净化には, 透析膜として EVAL 膜 (KF-10C), 膜面積 $1.0 \mathrm{~m}^{2}$ を使用し, 抗凝固剤はメシ ル酸ナファモスタットを $5 \sim 10 \mathrm{mg} / \mathrm{h}$ と少量使用し た。

\section{3. 血液データ, 血行動態の推移（表 3)}

血液検查結果は, 人工心肺前の BUN $72 \mathrm{mg} / \mathrm{dL}$, $\mathrm{Cr} 8.9 \mathrm{mg} / \mathrm{dL}$, 血清 $\mathrm{K} 7.59 \mathrm{mg} / \mathrm{dL}$ が最高值を示 し, 術中, 術後は, $\mathrm{BUN}, \mathrm{Cr}$, 血清 $\mathrm{K}$ は, 各種血液 浄化によりコントロールでき, 輸血, 心筋保護によ る高 $\mathrm{K}$ 血症は認められなかった。術後, 血液浄化に よる出血傾向の増悪も認められなかった。

\section{III. 考 察}

維持透析患者の心大血管手術周術期は, 掔機能廃 絶による体液, 電解質の恒常性欠如が考えられ, 高 窒素血症と術中の心筋保護液や輸血による高 $\mathrm{K}$ 血 症が予想されるため，尿毒素の除去，水分バランス， 電解質の補正を目的に, 術前, 術中, 術後に管理さ れた血液浄化が必要である

維持透析患者に対して, 人工心肺中の血液浄化法
表 3 血液データ,血行動態の推移

\begin{tabular}{|c|c|c|c|c|c|c|c|}
\hline & & 0 & 1 & 2 & 3 & 4 \\
\hline & & 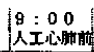 & 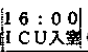 & $\begin{array}{l}7: 0 \\
\text { CHDF前 }\end{array}$ & $\begin{array}{l}7: 00 \\
\text { HD前 }\end{array}$ & $\begin{array}{l}7: 00 \\
\text { HD物 }\end{array}$ & $\begin{array}{c}7: 00 \\
\text { HDな }\end{array}$ \\
\hline $\begin{array}{l}B U N \\
C r \\
\text { 血清 } \mathrm{K} \\
\mathrm{HCt}\end{array}$ & $\begin{array}{l}\mathrm{mg} / \mathrm{dl} \\
\mathrm{mg} / \mathrm{dl} \\
\mathrm{mEq} / \mathrm{d} \ell \\
\%\end{array}$ & $\begin{array}{r}72 \\
8.9 \\
7.6 \\
36.2\end{array}$ & \begin{tabular}{r|}
38 \\
4.6 \\
5.1 \\
26.7
\end{tabular} & $\begin{array}{ll}5 & 1 \\
5.4 \\
5.2 \\
32.9\end{array}$ & $\begin{array}{r}50 \\
4.1 \\
5.2 \\
31.8\end{array}$ & \begin{tabular}{|c|}
4.4 \\
3.2 \\
5.2 \\
32.3
\end{tabular} & $\begin{array}{l}53 \\
3.2 \\
3.9 \\
39.3\end{array}$ \\
\hline $\begin{array}{l}\text { CVP } \\
\text { 出血量 }\end{array}$ & $\begin{array}{l}\mathrm{mmHg} \\
\mathrm{ml}\end{array}$ & 19 & $\begin{array}{lll}1 & 5 \\
7 & 8 & 0\end{array}$ & $\begin{array}{l}17 \\
345\end{array}$ & $\begin{array}{lll}1 & 5 \\
2 & 7 & 5\end{array} \mid$ & 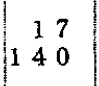 & $\begin{array}{l}\text { 披去 } \\
\text { 抜去 }\end{array}$ \\
\hline
\end{tabular}

は，様々な方法が報告され，主に人工心肺回路内の ECUM，人工心肺回路内に ECUM ではなく各種血 液浄化を用いる方法, ECUM と各種血液浄化を併用 する3つの方法が考えられる。

維持透析患者の術前管理 (連日の HD) が可能な待 機的な心大血管手術であれば, 人工心肺中, 積極的 に ECUM を行うことで, 体液, 電解質の恒常性は十 分維持できる”が，本症例のような緊急手術の場合， 高窒素血症, 高 $\mathrm{K}$ 血症の改善を図り, 術後血液浄化 開始を遅延するためには, ECUM と短時間で最も除 去能, 電解質の補正が優れた HD の選択が望まし (2)と考えられた。

術後, 血液浄化の開始は, 循環動態の影響の少な い腹膜透析が有効な成續であったと報告されてい

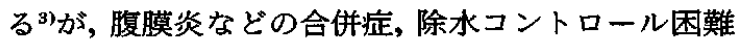
などが考えられるため, 血行動態の変動を最小限に 抑えながら，除水が行える CHDF が望ましいと考 えられる。本症例では, 術前, 高血中尿素窒菜値, 高血清 K值であったにもかかわらず，術中 $\mathrm{HD}$ を併 用することにより術直後急性期に尿瑇症や高 $\mathrm{K}$ 血症 
を来たすことなく管理でき, 呼吸状態が悪化した時 点で水分補正を目的とした CHDF のみで第 1 病日 を乗り切ることができた。血行動態が安定した第 2 病日より CHDF から HDに切り替え積極的に除水 することで，早期抜管が可能となったと考えられる。

維持透析患者の術後, 血液浄化の合併症として, 特に出血傾向の増悪が奬念される。本症例では, 術 後から 24 時間までの血液浄化開始回避が可能であ り, 抗凝固㓲にメシル酸ナファモスタット4と抗凝 固性の優れた EVAL 膜(5)使用することにより，少 量の抗凝固剤の使用で長時間の血液浄化が可能であ り, 出血傾向の堌悪も認められなかった。

しかし, EVAL 膜は, HD 用に開発された膜であ り, 疋田ら"は CHDF で使用した場合, 他の CHDF 用の膜(PMMA 膜) と比較すると, アルブミン損失, IL-6 などの mediator の除去に劣ると報告してお り, 長時間の CHDF で使用する場合は, これらを十 分考慮し, 患者の状態にあった膜を選択する必要が あると考えられる。

本症例では, 人工心肺中, ECUM と HD を併用す ることで, 早期に抜管, 一般病棟へ転床となり, 通 常の HDへ移行できたため, 以上のことから有用な 方法であったと考えられた。今後, 心大血管緊急手 術が必要とされる維持透析㭧者の救命率を向上する ためには, 患者の状態を把握し, 最も適した血液浄 化法を検討し, 選択する必要性があると考えられる。

\section{IV. 結 語}

(1). 維持透析患者の緊急心大血管手術に人工心肺 復温中, ECUM と HD を併用した。

(2) 血行動態が不安定な時期の血液浄化回避が可 能であった。

(3) 術後, 血液浄化による出血傾向の增悪は認め られなかった。

\section{- 参考文献}

1）澤田吉英, 森本大成, ほか：透析患者のバイパス術 の成續. 日胸外会誌，46；983-986，1998.

2 ）小宮山信一, 中野佐保里, ほか：㙰不全患者の人工 心肺施行中に併用する血液透析と血液滤過の比較. 長 野県透析研究会, 22(1)；65-66，1999.

3）寺岡 慧, 佐々木優里, ほか：透析感患者の心臓手 術における管理上の問題点. 日透析医会誌，21(6)； 545-549, 1988.

4）松田兼一, 平澤博之, ほか：抗凝固剂. 策中治療, $9(2): 215-220,1997$.

5) 正田 聡, 平澤博之, ほか：抗凝固剤を用いない (CHD) の検討. 集中治療, $10 ： 57-58,1998$. $\left.\begin{array}{l}\text { 本論文は, 第 } 27 \text { 回日本体外循環技術研究会大会にて } \\ \text { 報告した。 }\end{array}\right]$ 